\title{
Protein Lin-28 Homolog A
}

National Cancer Institute

\section{Source}

National Cancer Institute. Protein Lin-28 Homolog A. NCI Thesaurus. Code C73459.

Protein lin-28 homolog A (209 aa, $\sim 23 \mathrm{kDa}$ ) is encoded by the human LIN28A gene. This protein is involved in the inhibition of processing of pre-let-7 miRNAs and translational enhancement. 